Major Toppin, was a trained naturalist, and was able to make the most of his opportunities. Several new butterflies and a new monkey were the permanent testimonials to his skill. One is rather inclined to lament that it is not always possible to take the opportunity of a boundary survey and, by, attaching, say, a naturalist, a geologist, and possibly a botanist to the commission, gain much knowledge without great cost. Doubtless this practice might be often followed, but it must be remembered that a boundary commission is always in a hurry; it never has enough time to carry out all the survey observations it would like, and routes, times, and halting-places must be regulated solely by survey considerations. It would, therefore, often result that the naturalist or geologist would have to leave almost untouched the regions most fruitful of promise for him, and might return from the expedition with feelings of disappointment at opportunities missed.

We have no space here to enter upon any close discussion of the technical points raised in this report. The survey was of the class already familiar in similar undertakings, and was subject to the same obstacles as those found in previous surveys, both in high mountains and in dense forests : the difficulties of transport, the prevalence of mist and cloud, the impossibility of getting distant views from the constricted valleys, and, in the forest portion of the line, a horrible abundance of malignant insects. Once again, possibly for the last time, an effort was made to determine longitudes by occultations, a method which cannot attain the precision requisite for such work, and should be entirely superseded by wireless signals, which can now be received upon instruments of almost any desired degree of portability. In any case, astronomically determined positions are of little value as a check upon a triangulation even of the second order, and are of more interest to the geophysicist than to the boundary surveyor. This commission was fortunate in finding a wellestablished initial point for the astronomical work in the observatory at Arequipa, the southern station of the Harvard College Observatory.

An interesting little note by Sir C. Close is embodied in the report discussing the gravity deflections in the boundary region, and showing that the local attractions are quite similar to those found in the region of the Himalayas near Mussoorie and Dehra. The volume, produced in the accustomed high standard of the Cambridge University Press, is furnished with all the necessary maps and a rich selection of illustrative plates. We can heartily commend it, both to the reader of the present day as an account of a highly successful piece of geographical survey, and to the reader of the future as an imperishable record of the work that can be accomplished, in spite of innumerable difficulties and in face of great natural obstacles, by a small but thoroughly proficient British survey party.

E. H. H.

\section{THE AIR FORCE ESTIMATES AND AERONAUTICAL RESEARCH.}

C HE development of military aviation has been one of the wonders of the war, but we have naturally been kept somewhat in the dark as to the exact extent of such development while the war was still in progress. The veil has now been lifted, and Gen. Seely, in speaking on the Air Estimates in the House of Commons on March ${ }^{3} 3$, has given us a striking summary of the progress made during the past four years. The fact that the expenditure on the Air Force has increased two-hundred-fold since the outbreak of hostilities is a sufficient comment on the enormous advances that have taken place in the aeronautical world. Gen. Seely states that if the armistice had not been signed, this year's Estimates would have reached the sum of $200,000,000 l$. - an amount which is practically four times our pre-war expenditure on the entire Navy! Even with the signing of peace in sight the sum of 66,500 ;0ool. is asked for, in order to ensure the maintenance of the aerial supremacy which we have gained during the war.

It is exceedingly gratifying to note that the true value of research is at last being appreciated, and the specific provision of $3,000,000 l$. for " civil aviation, experiments, and research" will be welcome news to those who hope for the scientific development of commercial flying. Gen. Seely further points out that this sum does not by any means represent the total amount that will be spent on research beneficial to the civilian aviator, since the results of experiments carried out for military purposes and paid for out of the Army Estimates will be equally available for the improvement of commercial machines.

The Government has decided that it cannot itself undertake commercial flying, but that it will do everything in its power to give encouragement and protection, and it is already announced that the Postmaster-General is prepared to give contracts to private firms which are able to offer approved machines for postal services. Moreover, the Government will place most of the military aerodromes of the country at the disposal of civilian pilots for a small fee, and this alone should do much to encourage civilian flying.

In the course of his speech Gen. Seely announced that an important invention in wireless telephony had recently been made, by means of which the wireless operator in an aeroplane was able both to send and to receive messages. It was possible during the war for the leader of a scouting aeroplane squadron to communicate with the others, but it was not practicable to receive an answer. A vacuum valve generator was employed to generate smooth oscillations in the hanging aerial, and a vacuum valve magnifier with a crystal rectifier was used as the receiver. The experimental apparatus was in use in pre-war days, but it required years of research to make it practical and trustworthy. We congratulate the

NO. 2577 , VOL. IO3] 
Air Board research department on having overcome all the difficulties.

The promise for the future of aviation is very bright, and the recognition of the necessity for continuous research in the development of both military and civilian aeronautics leaves little doubt that the resources of scientific investigation, which have been of incalculable value during the war, will be fully employed in the solution of the oroblems of the future.

\section{LUDVIG SYLOW.}

$\mathrm{T}^{\mathrm{H}}$ $\mathrm{E}$ death of Ludvig Sylow (September 7, 1918 ), at the age of eighty-five, has removed an eminent mathematician, whose career was in many ways remarkable. Sylow's seventh published paper ("Théorèmes sur les groupes' de substitutions") occupies less than ten pages in vol. v. of the Mathematische Annalen (1872); this contains the proof of his justly celebrated theorem about groups, which has perhaps done more than any other single proposition to advance our knowledge of groups in general. In spite of this great achievement, Sylow had to earn his living as a secondary-school teacher until he had served a term of forty years. Recognition came at last; he was made professor at Christiania at the age of sixty-five, and filled the chair successfully for twenty years.

It may be of interest to recall Sylow's own statement of his theorem: "Si $n^{a}$ désigne la plus grande puissance du nombre premier $n$ qui divise l'ordre du groupe G, ce groupe contient un autre $g$ de l'ordre $n^{\alpha} ;$ si de plus $n^{\alpha} v$ désigne l'ordre du plus grand groupe contenu dans $\mathrm{G}$ dont les substitutions sont permutables à $g$, 1'ordre de G sera de la forme $n^{a} v(n p+r)$." It should be noted that Sylow gives a proof that, if $n^{a}$ is the highest power of $n$ contained in the order of $\mathrm{G}$, then $\mathrm{G}$ contains a subgroup of order $n^{a}$.

Sylow wrote a number of other papers, dealing with such topics as group-theory, solution of equations by radicals, elliptic functions, modular functions, etc. In collaboration with Lie he undertook the arduous task of editing the second issue of Abel's works. In this the misprints and oversights of the original edition are corrected, and a number of valuable notes and comments by the editors are added.

G. B. M.

\section{NOTES.}

THE appointment of Dr. S. F. Harmer to succeed Sir Lazarus Fletcher as director of the Natural History Museum, South Kensington, is a happy. solution of the question raised by the letter from twenty-three naturalists published in NATURE of March 6, and commented upon by us in the same issue. Dr. Harmer has been keeper of the Department of Zoology of the museum since 1907 , and he will retain this position until the end of next year. During this transition period Mr. C. E. Fagan, the assistant secretary, will assist him in the control of the museum, and, in recognition of his valuable services, will occupy a No. 2577 , vOL. IO3] considerably improved position on the staff. Mr. C. Tate Regan has been appointed assistant keeper of zoology in succession to Mr. W. R. Ogilvie Grant, who has retired. As the Trustees have appointed a distinguished naturalist to the directorship of the museum, the series of eminent scientific men who have occupied that post remains unbroken. It is the duty of men of science to guard jealously their claims to direct the affairs of scientific institutions, and to protest when any encroachment upon them is contemplated. In the present instance Mr. Fagan was more than a purely lay administrator, and his scientific services have been appropriately, recognised by the Trustees. The tendency is, however, to place lay administrative officers in control of State institutions concerned with scientific work, on the ground that a man of science cannot be a good administrator. Even if this general belief, cherished in the Civil Service, could be justified-and we do not accept it for a moment-the highest office in a scientific institution should be held by a scientific man, and not by a lay official. That is the whole point of our contention, and we are glad that the Trustees have accepted what is the feeling of scientific men generally in regard to it by appointing Dr. Harmer to the vacant post, which he is highly qualified to fill.

LORD SUDELEy is to be thanked for having brought the House of Lords to such a high appreciation of museums as educational instruments that, on March 12, in the face of some Government objections, it wholeheartedly agreed to his motion:-“'That his Majesty's Government should, without further delay, reinstate the system of providing official guide-lecturers for the museums and picture galleries under the control of the Government, which, with one exception, has been in abeyance during the war, making such addition to the numbers and in the salaries and status of the guides as may be found necessary." The Government, it seems, is prepared to reinstate the pre-war conditions, but is not prepared to increase the numbers or salaries of the guide-lecturers; neither does it act with promptness in clearing the museums of alien departments. There can be no doubt as to the popular feeling in this matter, and when, twice within a fortnight, it is supported in the Upper Chamber by men of such weight as Lords Crewe, Harcourt, Meath, Morris, Gainford, and Rathcreedan, then a Government which contains many sympathetic elements should surely be emboldened to spend the relatively minute sum needed to set all this valuable educational machinery in motion. His Grace the Archbishop of Canterbury urged that an increased number of guides would permit the extension of co-operation between the British Museum and the primary schools through lectures to the teachers, who would then take their classes to the museum; there could also then be an extension of similar aid to schools of art and secondary schools. Incidentally, the Primate took occasion to extol the merits of the British Museum guide-books, from which, he rightly said, visitors might derive much advantage. Can he be aware that the General Guide to the Natural History Museum has been out of print for some years, and that a sale of many thousands to the visiting troops and others has thus been lost? A new edition of this guide should be an early claim on the time of the new director.

THE question of long-distance wireless telegraph communication is now engaging the attention of a Committee recently appointed by the War Cabinet, with Lord Milner as chairman. The need for action 